\title{
REDES DE EMISSÕES E POLÍTICA NO BRASIL
}

Eder Johnson de Area Pereira1; Anderson da Silva Palmeira2; Luiz Carlos De Santana Ribeiro3;Hernane Borges de Barros Pereira2

1,2Centro Universitário SENAI CIMATEC, Av. Orlando Gomes 1845 - Piatã; Salvador/Bahia; andersonpalmeira@icloud.com 3Universidade Federal de Sergipe, Brasil

Resumo: Desde sua posse em 1ํ de janeiro de 2019, Jair Bolsonaro, um candidato de direita declarado conhecido como Trump Tropical, introduziu medidas para reduzir as restrições ambientais à pecuária, o principal setor produtor de gás de efeito estufa (GEE) no Brasil e o responsável por a maior parte do desmatamento no país. Essa perigosa relação entre política e pecuária no Brasil é prejudicial à conservação ambiental. Os políticos estão introduzindo medidas que facilitam a expansão deste tipo de agricultura, que por sua vez fornece insumos para a indústria alimentícia, ou seja, o agronegócio, que por sua vez financia a política, produzindo um ciclo perigoso para a conservação da floresta.

Palavras-Chave: Política; Bolsonaro; Amazônia; Agronegócio; GEE emissões.

\section{EMISSIONS NETWORKS AND POLITICS IN BRAZIL}

Abstract: Since his inauguration on January 1, 2019, Jair Bolsonaro, a declared rightwing candidate known as Trump Tropical, has introduced measures to reduce environmental restrictions on livestock farming, the main greenhouse gas (GHG) producing sector in Brazil and the one responsible for most of the deforestation in the country. This dangerous relationship between politics and livestock farming in Brazil is detrimental to environmental conservation. Politicians are introducing measures that facilitate the expansion of this type of farming, which in turn provides inputs for the food industry, i.e. agribusiness, which in turn finances politics, producing a dangerous cycle for forest conservation.

Keywords: Policy; Bolsonaro; Amazon; Agribusiness; GHG emissions. 


\section{INTRODUCTION}

Bolsonaro assumed the Brazilian presidency and, in exchange for political support, mainly of the ruralist group (deputies and senators who are linked to Brazilian agribusiness) he has introduced several measures that encourage the expansion of agriculture and livestock. Among them is a drastic reduction in funds for forest inspection and control agencies, freer use of agrochemicals, loosening of environmental licenses and the transfer of the demarcation of indigenous lands to the Ministry of Agriculture.

In this context, several studies deal with the influence of Brazilian politics on global sustainability. [1] states that the influence of politics in Brazil threatens the Amazon, mainly supporting large investment projects in the Amazon such as dams and roads and [2] have identified that cuts in agencies that oversee the Amazon such as: Brazilian Institute of Environment and Renewable Natural Resources (IBAMA) and Chico Mendes Institute for Biodiversity Conservation (ICMBio) may cause damage to forest conservation.

It can also be highlighted that complex networks have contributed to the economy by proposing new methods, techniques and properties [3]. One example is the adoption of free-scale networks [4], which according to [5] are networks that have a degree distribution in the form of a power law to explain various economic phenomena.

The Ecological Networks has been consolidated as a method to evaluate how the diverse exchanges involving regional or global economic sectors affect the emission of greenhouse gases. Thus [6] analyzed the effect of global global transactions on $\mathrm{CO} 2$ emissions, noting the existence of two large emitting communities, with emphasis on the civil construction sector in China. And [7] used network properties to calculate which sectors have a central role in $\mathrm{CO} 2$ emissions.

We evaluate the sectorial emissions relationships involving the Brazilian economy using network theory and we find that the sectors that emit most greenhouse gases are related to livestock, agriculture and the food industry, all sectors related to the ruralist group. This paper demonstrates how these measures contribute to the high GHG emissions in the environment, from laws that facilitate the expansion of livestock which, in turn, provides cattle for the food industry that finances the policies, producing a conflict and dangerous cycle for forest conservation.

\section{Six Months of Bolsonaro Presidency}

Among the most controversial measures introduced is the cut to the budget of the Ministry of the Environment, which is responsible for the agencies that directly supervise the Amazon forest, such as the Brazilian Institute of Environment and Renewable Natural Resources (IBAMA) and Chico Mendes Institute for Biodiversity Conservation (ICMBio).

The government cut $95 \%$ of the National Policy on Climate Change budget, $26 \%$ of the Federal Conservation Management and Implementation Program, $24 \%$ of IBAMA's Inspection and Control Program, and 20\% of Environmental Inspection, Prevention and Control of Forest Fires Program of the ICMBio. The ICMBio alone is 
responsible for 327 units of Federal Conservation, corresponding to 75.9 million hectares of land [2].

Some these cuts involve discretionary expenses, such as buying fuel for the vehicles to monitor the forest, and the lodgings of the agents who combat deforestation. In May 2019 alone, the National Institute for Space Research [16] registered $739 \mathrm{Km} 2$ of deforestation in the Legal Amazon. This represents a 34\% increase compared to May 2018. If deforestation continues at this rate in 2019, it may reach the highest rate since 2008, surpassing even 2018, when the area deforested was $7,900 \mathrm{~km} 2$.

Deforestation in the Amazon is dramatic because it is the largest rainforest in the world, sheltering a quarter of the planet's fauna and flora. Deforestation increases greenhouse gas emissions due to the liberation of carbon from the forest and soil biomass. Amazon conservation prevents changes in climate, temperatures and droughts [8].

In order to improve its governability, Bolsonaro has made alliances with parliamentary groups that have interests contrary to environmental conservation. Clearly the rural bench is made up of parliamentarians who are businessmen linked to Brazilian agribusiness. With 257 deputies, the ruralists represent $50 \%$ of the House, which is made up of 513 parliamentarians. In the Senate, ruralists hold 32 of the 81 seats, or $39.5 \%$.

The agribusiness lobby on government also prompted the authorization of the import and use of 211 pesticides. Thus, 2019 has already been the year with the greatest release of pesticides in Brazilian agriculture. Near $40 \%$ of the new products are highly toxic and $28 \%$ of these products have been banned or are not allowed by the European Union. There are glyphosate-containing products that are classified by the International Agency for Research on Cancer (IARC) as potentially carcinogenic to humans (category 2A) and are associated with a number of cancer cases in the US justice system.

In Congress the Bill (PL 3,729/2004), attached to PL 2,942/2019, which reduces environmental requirements, creates self-declaratory licensing, and exempts licensing for specific polluting activities. This will facilitate new infrastructure investment in environmentally protected areas. In turn, this encourages the construction of dams, highways and hydroelectric power plants in the Amazon, with negative effects on forest conservation.

In another controversial step, President Jair Bolsonaro issued provisional measure no. 886 [9] of June 18, 2019, amending article 21 of Law no. 13,844, which removes the responsibility for the demarcation of indigenous and "quilombolas" lands from the National Indian Foundation and passes it on to the Ministry of Agriculture, headed by the ruralists. This represents a setback, and an affront to the 1988 Constitution, which established the legal framework for demarcation. It should be noted that indigenous lands and other protected areas, created to safeguard land rights, indigenous livelihoods and biodiversity, contain more than 312 billion tonnes of carbon (GtC) [10]. In addition Bolsonaro dismissed the director of INPE (National Institute for Space Research), which monitors deforestation in the Amazon, Ricardo Galvão for disclosing data on the increase of deforestation in the Amazon. 


\section{METHODS}

The input-output model represents the trade relations between economic sectors and components of final demand in a given period. The model's solution can be specified, according to [11], as $x=L y$, where $x$ is the sectoral output vector, $L$ is the Leontief Inverse matrix, that is, $L=(I-A)^{-1}$ and $y$ is the final demand vector. $A$ is defined as the Technological matrix, i.e., $A=\left[a_{i j}\right]=\frac{z_{i j}}{x_{j}}$, where $z_{i j}$ is the trade relationship between sectors $i$ and $j$. The main difference between the matrices $A$ and $L$ is that while the former only captures the direct relationship between the sectors, the Leontief Inverse matrix also captures the indirect relationship and therefore is also known as the Total Impacts Matrix (direct and indirect effects).To incorporate GHG emissions into the input-output framework, we initially need to define the emission coefficient, i.e., $c_{j}=\frac{\theta_{j}}{x_{j}}$, where $e_{j}$ is the GHG emissions vector of sector $j$. Thus, $c_{j}$ is the total GHG emissions generated per unit of output of sector $j$, that is, the direct effect [12]. We can define the total volume of GHG emissions produced in the economy as $c_{j}=\hat{c}_{j} L f=\hat{c}_{j} X$, where $\hat{c}_{j}$ is the diagonalised emission coefficient. We use the latest available Brazilian input-output matrix, base year 2015, published by the Brazilian Institute of Geography and Statistics (IBGE) and GHG emissions' data from the National Emissions Registration System of Ministry of Science, Technology, Innovations and Communications. The share of livestock on deforestation came from the Food and Agriculture Organization of United Nations. To calculate the weighted output degree centrality we use as reference [13].

\section{RESULTS AND DISCUSSION}

Livestock is the activity that most deforests the Amazon forest causing carbon dioxide (CO2) emissions through land use change. In addition to these emissions, livestock emits large amounts of enteric methane $(\mathrm{CH} 4)$ as a result of the biological processes of ruminant digestion [14].

When we analyze the environmental network of GHG emission1 (Figure 1) for Brazil in 2015, we can see that the Livestock sector is the hub of the network. Part of the agribusiness productive chain accounts for most GHG emissions in Brazil. Nevertheless, these sectors (Agriculture, Livestock and Food and Beverage Industry, in red) are responsible for the three largest sectorial emissions embodied in trade in Brazil (considering the weighted out-degree network metric that captures how much GHG a sector emits in a traded relationship with another). In addition, the livestock and food and beverage industries have the highest GHG emissions sector ratio because the food industry requires inputs and outputs from livestock, causing very high GHG emissions in the latter, both through the cattle fermentation of $\mathrm{CH} 4$ and $\mathrm{CO} 2$ emission

\footnotetext{
${ }^{1}$ This network was built from the trade flows of the Brazilian Input-Output Matrix and GHG data. To better understand the model, see the Supplementary Material.
} 


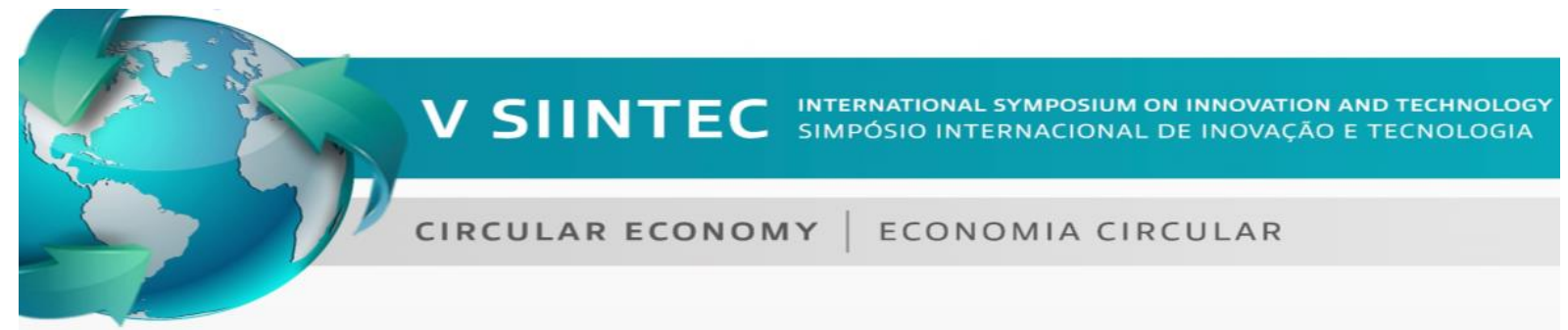

from land use change. For each $R \$ 1,000$ of variation in livestock's final demand, 532.6 $\mathrm{t} / \mathrm{CO} 2 \mathrm{e}$ in the Brazilian economy are generated, $43.4 \mathrm{t} / \mathrm{CO} 2 \mathrm{e}$ in agriculture, 432.4 $\mathrm{t} / \mathrm{CO} 2 \mathrm{e}$ in livestock itself and $2.7 \mathrm{t} / \mathrm{CO} 2 \mathrm{e}$ in food and beverage industry.

Figure 1: Sectorial network of greenhouse gas emissions in Brazil, 2015.

Source: Author's own

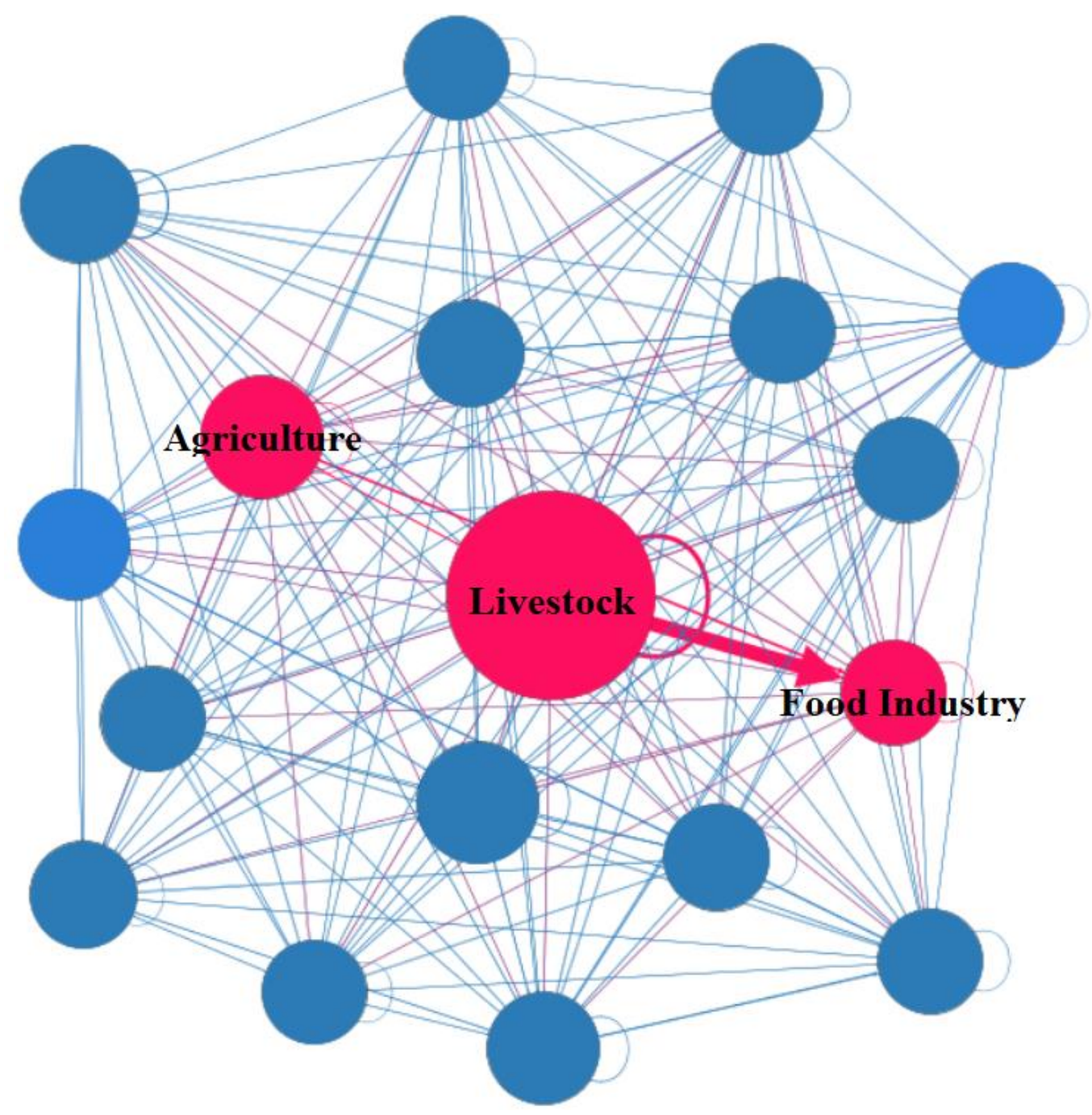

\subsection{A Dangerous Cycle}

Agribusiness finances the Brazilian ruralist group, either through agriculture and livestock or large conglomerates linked to the food industry [15]. This deepens a 
dangerous cycle against forest conservation (see Figure 2). The President, along with the respective parliament and senate groups, pass laws that favor the unregulated expansion of livestock. Cattle raised on deforested farms are sold to the food industry that exports part of what is produced. The agribusiness finances its benches in Parliament and the Senate2, which vote in favor of the increase in cattle raising, restarting the cycle.

Figure 2: Cycle of deforestation in livestock, emissions and policy. Source: Author's own.

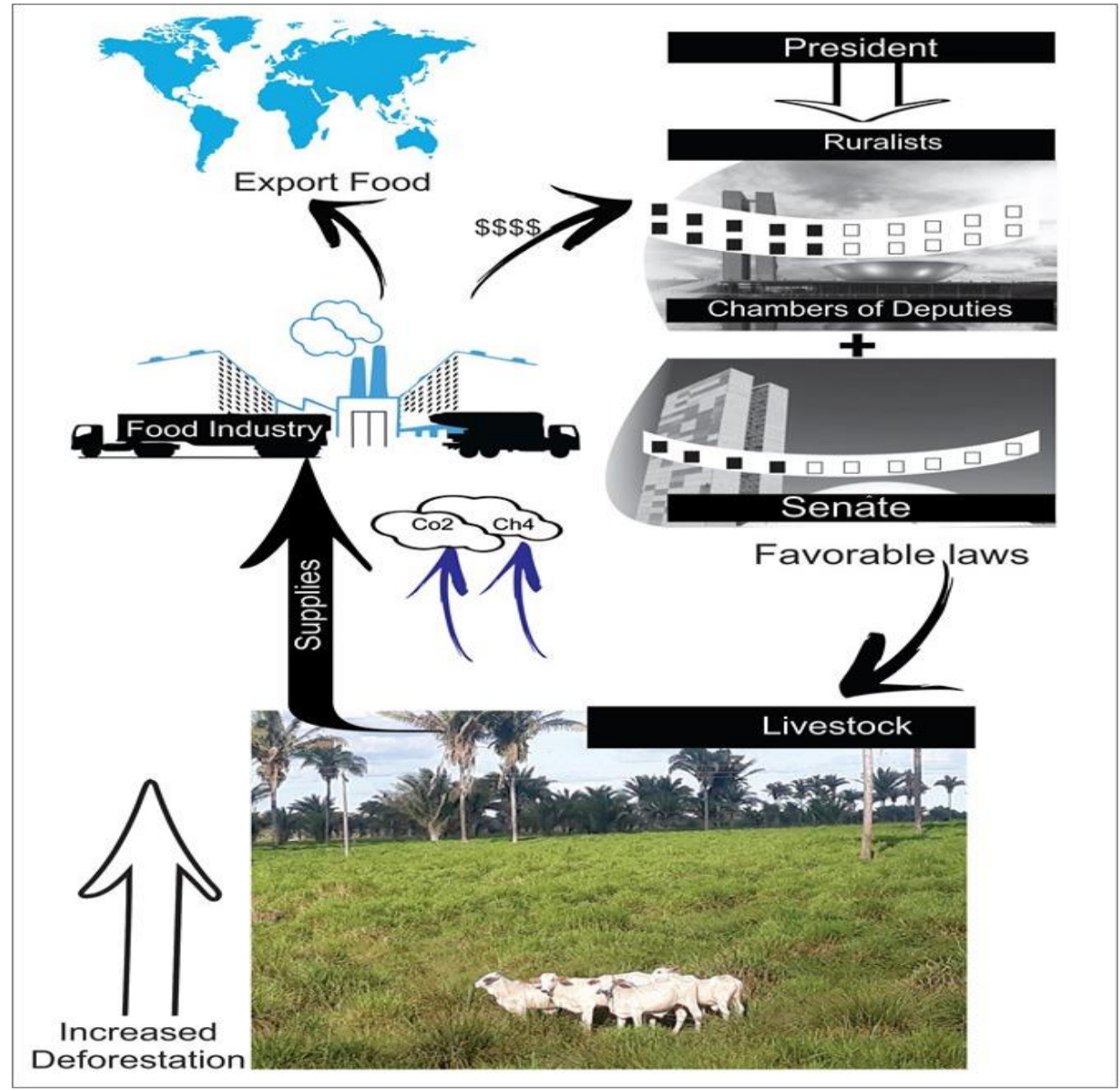

\footnotetext{
${ }^{2}$ The JBS Company, the country's top frigorific industry only in the 2014 election, donated nearly U\$ 155 million to politicians and parties.
} 


\section{CONCLUSION}

One way to try to reduce further deforestation is to return to the Soy Moratorium, an environmental pact established between 2006 and 2016 among environmentalists, farmers and nongovernmental organizations. It sought to reconcile economic development with responsible and sustainable use of natural resources. During this period, the Brazilian Association of Vegetable Oil Industries and the Brazilian Association of Cereal Exporters and their respective associates pledged not to market soybeans from deforested areas within the Amazon biome. The soy moratorium practically zeroed deforestation in the Brazilian Amazon. In addition, there is potential for the growth of commodity production in the region without the need for additional deforestation.

Another measure would be the Meat Moratorium, in which large industries would only buy meat from companies that had signed the Meat Beef Adjustment Agreement in the Amazon. It establishes that illegal deforestation should not occur within the Amazon Biome, and that the limits defined by the Brazilian Forest Code must be respected. It delimits $80 \%$ of the forest area in a private property that be preserved as a Legal Reserve area located in the Amazon. It is necessary that the private properties adhere to the Rural Environmental Register (CAR), a system that maintains the limits of the properties to do environmental georeferencing. This would combat the problem in two ways as it would help reduce emissions from land and forest use and reduce emissions from trade relations between agriculture and food sectors. Another measure could come from the European Union who imported $U \$ 500$ millions worth of Brazilian meat. This accounted for $17.6 \%$ of Brazil's total exports. The EU could require that these products should not come from deforested areas and thus condition bilateral trade to sustainable practices in Brazilian livestock.

The present Brazilian government's policy of slackening of environmental control can profoundly affect sustainability in Brazil, which since ECO-92 had been playing a leading role in combating global climate change and had drastically reduced deforestation in the Legal Amazon in the period 2004-2012. This ecosystem should not be threatened by governments nor political groups that put self-interest first. The environmental and social cost of such decisions can harm the entire planet. The mobilization of civil society and the pressure of the international community are necessary to avoid irreversible losses.

\section{REFERÊNCIAS}

1 FEARNSIDE, Philip M. Brazilian politics threaten environmental policies. Science, v. 353, n. 6301, p. 746-748, 2016.

2 PEREIRA, Eder Johnson de Area Leão et al. Policy in Brazil (2016-2019) threaten conservation of the Amazon rainforest. Environmental Science \& Policy, v. 100, p. 8-12, 2019. 
3 PEREIRA, Eder Johnson de Area Leão; DA SILVA, Marcus Fernandes; PEREIRA, HB de B. Econophysics: Past and present. Physica A: Statistical Mechanics and its Applications, v. 473, p. 251-261, 2017.

4 BARABÁSI, Albert-László; ALBERT, Réka. Emergence of scaling in random networks. science, v. 286, n. 5439, p. 509-512, 1999.

5 JACKSON, Matthew O. Social and economic networks. Princeton university press, 2010.

6 KAGAWA, Shigemi et al. CO2 emission clusters within global supply chain networks: Implications for climate change mitigation. Global Environmental Change, v. 35, p. 486-496, 2015.

7 HANAKA, Tesshu et al. Finding environmentally critical transmission sectors, transactions, and paths in global supply chain networks. Energy Economics, v. 68, p. 44-52, 2017.

8 FEARNSIDE, Philip M.; LAURANCE, William F. Tropical deforestation and greenhouse-gas emissions. Ecological Applications, v. 14, n. 4, p. 982-986, 2004.

9 Brasil. Medida Provisória № 886, de 18 de junho de 2019.

10 RICKETTS, Taylor $\mathrm{H}$. et al. Indigenous lands, protected areas, and slowing climate change. PLoS biology, v. 8, n. 3, p. e1000331, 2010.

11 MILLER, Ronald E.; BLAIR, Peter D. Input-output analysis: foundations and extensions. Cambridge university press, 2009.

12 DE SOUZA, Kênia Barreiro; RIBEIRO, Luiz Carlos de Santana; PEROBELLI, Fernando Salgueiro. Reducing Brazilian greenhouse gas emissions: scenario simulations of targets and policies. Economic Systems Research, v. 28, n. 4, p. 482496, 2016.

13 NEWMAN, Mark. Networks. Oxford university press, 2018.

${ }_{14}$ CERRI, Carlos Eduardo Pellegrino et al. Reducing Amazon deforestation through agricultural intensification in the Cerrado for advancing food security and mitigating climate change. Sustainability, v. 10, n. 4, p. 989, 2018.

15 Inpe (Instituto Nacional de Pesquisas Espaciais). 2019. PRODES: Monitoramento da floresta Amazônica brasileira por satélite. http://www.obt.inpe.br/OBT/assuntos/programas/amazonia/prodes/ Accessed 16 june, 2019.

16 MEDEIROS, E. \& FONSECA, B. (2016). As bancadas da Câmara. Agência Pública, 18. 